\title{
Konrád Jenő adta a catatonia első magyar nyelvü, tudományos igényü leírását 1881/82-ben
}

\author{
Gazdag Gábor dr. ${ }^{1,2}$ - Takács Rozália dr. ${ }^{3,4}$ - Ungvari S. Gabor dr., ${ }^{5,6}$ \\ ${ }^{1} J a h n$ Ferenc Dél-pesti Kórház, Pszichiátriai és Addiktológiai Centrum, Budapest \\ ${ }^{2}$ Semmelweis Egyetem, Általános Orvostudományi Kar, Pszichiátriai és Pszichoterápiás Klinika, Budapest \\ ${ }^{3}$ Tóth Ilona Egészségügyi Szolgálat, Pszichiátriai Szakrendelő, Budapest \\ ${ }^{4}$ Semmelweis Egyetem, Általános Orvostudományi Kar, Doktori Iskola, Budapest \\ ${ }^{5}$ University of Notre Dame Australia, Fremantle, Australia \\ ${ }^{6}$ Division of Psychiatry, School of Medicine, University of Western Australia, Perth, Australia
}

A catatoniának mint jól körülírt pszichiátriai zavarnak a definiálása Kahlbaum nevéhez füződik, aki 1874-ben publikált könyvében írta le először önálló nozológiai egységként a tünetegyüttest. A magyar nyelvű szakirodalomban Konrád Jenő publikálta először két, cataton tüneti képet mutató beteg esetét 1881-ben az Orvosi Hetilapban, a következó évben pedig egy részletesebb elemzésben a catatonia okait igyekezett feltárni, saját vizsgálati eredményeit is ismertetve. Leírta a catatoniának a menstruációs ciklussal mutatott összefüggését, a társuló vegetatív tüneteket, felvetette az epilepsziával, illetve a nitrátanyagcserével való összefüggését. A neuropatológiai lokalizáció vonatkozásában a törzsdúcoknak tulajdonított a tünetek kialakulásában jelentőséget. A jelen közleményben az első magyar nyelvű catatoniaközlések értékelése mellett Konrád doktornak a catatonia patogenezisével kapcsolatos elméleteit is elemezzük korunk tudományos eredményeinek tükrében. Végül röviden méltatjuk Konrád Jenő eredményekben gazdag életútját, melynek csúcsán a lipótmezei Országos Elme- és Ideggyógyintézet főigazgatója volt 1905 és 1910 között.

A pszichomotorium zavaraira nagyobb tudományos érdeklődés a XIX. század második felétől irányult. Számos korai szerző - mint Pinel, Griesinger és Arndt - számolt be a későbbi catatonia fogalmával részben átfedést mutató klinikai állapotokról, mint „Katalepsie und Psychose”, „melancholie avec stupeur”, melyek többsége szokatlan motoros aktivitást, affektív tüneteket, vegetatív diszfunkciókat, illetve az akarati élet zavarait ölelte fel. A catatonia - mint jól körülírt pszichiátriai zavar definiálása a görlitzi magán-elmegyógyintézetet vezető Karl Ludwig Kablbaum (1828-1899) felülmúlhatatlan megfigyelési képességének és elemző elméjének köszönhető. 1874-ben publikált könyve [1] volt az első, amely önálló nozológiai egységként írta le a tünetegyüttest. Első leírásában különféle betegségek részeként megjelenő komplex klinikai képalkotó elemének vagy ezen betegségek átmeneti tüneti képének tekintette a cataton szindrómát.

Dr. Konrád Jenő 1854-ben született Veszprémben. Az egyetemet Budapesten végezte, 1875-ben gyógyszerészmesteri, majd az 1879/1880-as tanévben egyetemes orvosdoktori oklevelet szerzett. 1881-1882-ben a Budapesti Országos Tébolyda Női Osztályán dolgozott másodorvosként. Onnan publikált 1881-ben két, jellegzetes cataton tüneti képet mutató esetet [2], majd 1882ben további 2 esetet, kiegészítve a szindróma kialakulásának okára vonatkozó teóriákkal és saját vizsgálatának eredményeivel [3].

\section{Esetismertetések}

Az 1881-ben közölt mindkét eset a „catalepsia”, avagy „merevkór" tüneteit mutatta (a catalepsia az akaratlagosan szabályozható izomzat múködésének pszichés eredetû gátoltsága, a catatonia egyik tünete). Mindkét esetben nóbetegnél jelentkezett a tünetegyüttes, amit a szerző a menstruációs változásokkal hozott összefüggésbe.

Az elsó esetben egy 14 éves lánynál, normális menstruációs ciklus kialakulását követően fellépő menstruációs zavarhoz társultak a pszichomotoros tünetek, az ingerlékenység, dühösség. Első kezelése során tünetei gyorsan rendeződtek. 2 évvel később „4 napja tartó előrehaladott dühösség”, majd azt követően kialakult stupor (az akaratlagos mozgások teljes gátlása) miatt került ismételten felvételre az Intézetbe. Állapota 3 hónapos kezelése során jelentősen javult, szülei hazavitték. Az újabb osztályos felvételét megelőző 3 hónapban menstruációja kimaradását tapasztalták, majd krisztallizáció (cataton tü- 
net, amikor is a beteg valamilyen különös testtartásba merevedik), fokozott izomtónus és viaszhajlékonyság tünetei miatt (a beteg kezdetben passzívan ellenáll a végtagjai vizsgáló általi beállításának, de ez az ellenállás fokozatosan csökken, és végül a beteg fenntartja azt a testhelyzetet, amelybe a vizsgáló állította) 1880 májusában került ismételten felvételre. A beteg incontinens volt, árammal történő ingerlésre sem reagált. Októberig állapota hullámzó, jelentősen nem javul. Ekkor menstruációja visszatért, pszichés állapotában is fokozatos javulás indult, aminek eredményeképpen decemberben „gyógyultan" elbocsátható volt. Kezelése első 5 hónapjára a beteg amnéziás maradt.

A második eset egy 22 éves nő betegségének leírása, akinél a pszichomotoros tünetek - melyek lényegében azonosak voltak az előző beteg tüneteivel - 3 hónappal szülés után kezdődtek. Felvételekor a hüvelyből gennyes váladék szivárgott, a méhszáj körül sebek voltak láthatók, az előző hetekben visszatérően jelentkező alhasi görcsöket panaszolt. Állapota 6 hétig változatlan volt, majd lezajlott nála egy epilepsziás roham. Utána 4 napig „végtagjai hüdöttnek látszanak”, majd a viaszhajlékonyság visszatért. Néhány nappal később gyenge menstruáció jelentkezett, a folyás csökkent, a fekélyek tisztultak, és ezzel párhuzamosan pszichés állapota fokozatosan javulni kezdett. Viaszhajlékonyság hullámzóan még megjelenik, echopraxia (a beteg utánozza a vizsgáló mozdulatait) és parancsautomatizmus (az utasítások gondolkodás nélküli, gépies végrehajtása) is megfigyelhető. A következő 3 hónapban nőgyógyászati problémájának rendeződésével párhuzamosan pszichés állapota is javult, majd lényegében tünetmentesen otthonába távozott. A kezelése alatti időre ő is amnéziás.

Konrád a cataton tünetek és a mindkét esetben megfigyelhető nőgyógyászati, menstruációs problémák összefüggései mellett érvelt, amit a „méhidegfonaton” keresztül a központi idegrendszerre terjedő ingerülettel magyarázott. Az állapotot ezért organikus és nem „elmebántalom" eredetűnek tartotta. A catatonia kialakulásában szerepet tulajdonított a vazomotoros beidegzésnek is, valamint a vegetatív idegrendszer múködési zavarát is feltételezte. Végül párhuzamot vont a hipnózis során kialakuló állapot és a catalepsia tünetei között.

Konrád az 1882-ben publikált összefoglaló munkáját Kahlbaum megfigyeléseinek összefoglalásával kezdte. Bár leírta a catatonia általa megfigyelt jellemző zajlását (búkóros hangulat, dühösség, stupescentia, zavarodottság, majd gyógyulás), mégis a kórállapot heterogén volta mellett foglalt állást. Dolgozatában egy harmadik eset kapcsán írja le megfigyeléseit. A beteg állapotát felvételekor nyugtalanság, hangulati labilitás, hallucinációk jellemezték. Később lassan apatikussá vált, majd időszakosan izomrángásokkal kísért stuporos állapotok jelentkeztek. A gátoltsághoz alkalmanként viaszhajlékonyság is társult. Felvétele után 9 hónappal napokon keresztül ismétlődo”, elhúzódó görcsrohamai zajlottak. Izomtónusa egyre fokozódott, pulzusa, hőmérséklete emelkedett, arcpír, anesztézia alakult ki, szondán át táplálták. Kezelése 13. hónapjára a cataton tünetek jelentősen csökkentek, ekkorra a hallucinációk álltak előtérben. A betegnél előfordult beszédtüneteket, ismétléseket ( „vígy magaddal, magaddal, magaddal”), illetve a bizonyos helyzetekben visszatérően, kényszeresen megjelenő inadekvát verbális megnyilvánulásokat - Kahlbaum nyomán - a beszédközpont görcsös jelenségének tekinti.

A dolgozatban ismertet egy negyedik esetet is. Egy 19 éves nőbetegét, akinél vegetatív tónusfokozódással (kipirulás, szapora szívverés, fokozott verejtékezés) és beszéd-, valamint mozgásképtelenséggel járó rosszullétek zajlottak. A beteg ezek alatt visszatérően sérüléseket szenvedett. A rosszullétek alatt történtekről a beteg utólag beszámolt. A betegnél észlelhető vegetatív tüneteket Konrád oki összefüggésbe hozza a catatoniával. Az izomtünetek kialakulására másik teóriával is szolgál Svetlin [4] elmélete alapján. E szerint a törzsdúcok sejtjeinek gátolt állapota magyarázhatja a cataton tünetek kialakulását. Benedikt elmélete [5] viszont a tónusfokozódást fokozott ingerlékenységgel magyarázta. Konrád az agyi gátlás és az ingerlés váltakozását az agy anyagcseréjével és vérkeringésével hozza összefüggésbe.

Konrád a dolgozata végén Strübing nyomán [6] a catatoniának egy másik anyagcsere-összefüggését is igyekezett bemutatni. Bár saját vizsgálati eredményeiből arra a következtetésre jutott, hogy a vizelet foszfor- és "hugyany” (karbamid)-tartalma a cataton állapotokban csökken, ezt számadatai nem támasztották alá meggyőzően. A csökkent foszfortartalmat a mozgatóizmokat beidegző velőshüvelyek és a dúcsejtek károsodásával hozta összefüggésbe.

\section{Megbeszélés}

Konrád a közleményeiben a catatoniának az alábbi, később megerősített összefüggéseire világít rá.

\section{Hormonális hatások}

A női menstruációs ciklus és pszichotikus állapotok öszszefüggését Krafft-Ebing már Konrád közlése előtt 2 évvel leírta [7]. Menstruációs pszichózisok címszó alatt Brockington foglalta össze legutóbb minden részletre kiterjedő gondossággal a terület aktuális eredményeit [8]. A pszichomotoros tüneteket specifikusan ugyanakkor csak néhány éve hozták összefüggésbe a menstruációval $[9,10]$.

\section{Vegetativ tünetek}

A catatoniának a vegetatív szabályozás egyensúlyának felborulásával járó súlyos formáját (malignus catatonia) Kahlbaum könyvének megjelenése előtt már Calmeil [11] és Bell [12] is ismertették. A tünetegyüttes legismertebb leírása ugyanakkor Staudertől származik [13]. 
Az utóbbi években több összefoglaló közleményben is a catatonia és a delírium gyakori együttes megjelenését hangsúlyozták a szerzők [14, 15]. A Konrád által közölt esetekben csak enyhe, jelzett vegetatív tünetek jelentek meg, a kórlefolyás nem merítette ki a Stauder által leírt, rendkívül rossz prognózisú vagy a deliráns formát. Ugyanakkor Konrád kiváló megfigyelőképességét dicséri az enyhe vegetatív tünetek felismerése és leírása.

\section{Epilepszia}

A catatoniának az epilepsziával mutatott összefüggését igazolta az a retrospektív vizsgálat [16], amelyben 29, akut cataton tüneteket mutató neurológiai beteg közül 4-nél az epilepszia valamelyik formáját találták a tünetek hátterében. Két páciensnek dystoniás, egynek komplex parciális rohama, egynek pedig absence status epilepticusa volt. Egy esetleírásban epilepsziás rohamot követően kialakult, perzisztáló cataton állapotról számoltak be, amely antiepileptikumra nem, csak lorazepámra reagált [17].

\section{Laboreltérések}

A későbbi vizsgálatok Konrád feltételezései közül a nitrogén szerepét támasztották alá, elsősorban periodikus cataton állapotokban. Gjessing és Gjessing periodikus cataton betegek különböző klinikai állapotaiban vizsgálta a vér karbamid-nitrogén- és a vizelet ammónia- és karbamidtartalmát. A laborparaméterek változásai szoros időbeli összefüggést mutattak a cataton tünetek periodikus változásaival. A szerzők az észlelt periodicitást a hypothalamus múködésével hozták összefüggésbe [18].

\section{A törzsdúcok érintettsége}

A képalkotó vizsgálatok fejlődésével számos kutatás igazolta a törzsdúcok érintettségét a cataton tünetek kialakulásában. Az egyik legújabb vizsgálatban többváltozós adatfúziós technikát alkalmaztak mágneses rezonanciás (MR-) vizsgálat során, cataton tüneteket mutató és nem mutató szkizofrénia spektrumbetegségben szenvedő páciensek vizsgálatakor [19]. Kontrollcsoporttal összehasonlítva, a cataton tüneteket mutató pácienseknél a frontothalamicus és a corticostriatalis pályák eltéréseit mutatták a vizsgálatok.

Konrád Jenő catatoniáról szóló esetleírásai és egy cataton betegen végzett első vizsgálatának eredményei alig 7 évvel Kahlbaum korszakalkotó monográfiájának megjelenése után láttak napvilágot. Az új elméletet az 1870-es években sem a német, sem a nemzetközi tudományos közösség nem fogadta nagy lelkesedéssel, a nemzetközi szakirodalomban ekkor még csak egy német [20] és egy angol [21] közlemény jelent meg a catatoniáról. Kahlbaum elméletének gyors magyarországi megjelenését az is segíthette, hogy a XIX. század végének tudományos nyelve Magyarországon a német volt. Kahlbaum múvének megismerése a kor vezető magyar pszichiátereinek nem okozhatott problémát. Bámulatos ugyanakkor, hogy egy csekély klinikai tapasztalattal rendelkező, 27 éves magyar pszichiáter ilyen világosan meg tudta ragadni Kahlbaum koncepciójának lényegét, és éles szemmel alkalmazni tudta klinikai gyakorlatában az új elméletet, a kor vezető pszichiátereinek magabiztosságával. Sőt még tovább menve, Konrád doktor meggyőző hipotéziseket állított fel a catatonia patogeneziséről. Ezzel nemcsak az első magyar szakértője lett a témának, de megalapozta a biológiai gondolkodást is a magyar pszichiátriában.

Feltehetően a catatonia témakörében közölt fenti 2 cikk is hozzájárult ahhoz, hogy Konrád Jenő 1882-ben 3 éves külföldi ösztöndíjat kapott tudása elmélyítésére. Osztrák, német, angol és francia intézeteket látogatott meg ez alatt a 3 év alatt. Visszaérkezése után, 1886-ban a Nagyszebeni Állami Elmegyógyintézet (ma: Sibiu, Románia) igazgató fóorvosának nevezték ki. Megvetette a pszichiátriai betegek családi ápolásának alapjait. A Kolozsvári Egyetemen (ma: Cluj-Napoca, Románia) elmekórtant oktatott. 1905-ben a budapesti orvosegyetem magántanári címet adományozott neki. Ugyanebben az évben kapta meg a Lipótmezei Elmegyógyintézet igazgatói állását, amit 1910-ig, nyugdíjazásáig töltött be [22]. Halála 1919-ben következett be Budapesten.

\section{Köszönetnyilvánítás}

A szerzők köszönetüket fejezik ki Stephan Heckers professzornak, aki felhívta a figyelmüket Konrád Jenőnek a catatonia témájában, az Orvosi Hetilapban publikált cikkeire.

\section{Irodalom}

[1] Kahlbaum KL. The catatonia or tension insanity. [Die Katatonie oder das Spannungsirresein.] Verlag August Hirschwald, Berlin, 1874. [German]

[2] Konrád J. Two cases of mental disorder with symptoms of stupor. [Elmebántalom két esete merevkóros tünetekkel.] Orv Hetil. 1881; 25(51): 1189-1194, 25(52): 1214-1216. [Hungarian]

[3] Konrád J. Data regarding the theory of catatonia. [Adatok a catatonia tanához.] Orv Hetil. 1882; 26(36): 909-914, 26(37): 942-943, 26(39): 977-979. [Hungarian]

[4] Svetlin W. A contribution to the study of catalepsy. [Ein Beitrag zur Lehre von der Katalepsie.] Arch Psychiatr (Berlin). 1878; viii: 549-566. [German]

[5] Benedikt M. About catalepsy and mesmerism. [Über Katalepsie und Mesmerismus] Wiener Klinik: Vorträge; Jg. 6, H. 3/4, Vienna, 1880. [German]

[6] Strübing P. About catalepsy. [Über Katalepsie.] Deutsches Arch f klin Med (Leipzig). 1880-1881; xxvii: 111-128. [German]

[7] Krafft-Ebing R. Studies of insanity during menstruation. [Untersuchungen über Irresein zur Zeit der Menstruation.] Arch f Psychiatr. 1878; 8: 65-107. [German]

[8] Brockington I. Menstrual psychosis. World Psychiatry 2005; 4: 9-17.

[9] Kobayashi T, Kato S. Menstrual catatonia. Psychiatry Clin Neurosci. $2009 ; 63$ : 773-774. 
[10] Zwiebel S, Villasante-Tejanos AG, de Leon J. Periodic catatonia marked by hypercortisolemia and exacerbated by the menses: a case report and literature review. Case Rep Psychiatry 2018; 2018: 4264763. Doi: 10.1155/2018/4264763.

[11] Calmeil LF. Dictionary of medicine or general repertoire of sciences, medical considerations for theoretical and practical report. [Dictionnaire de médecine: ou, repertoire général des sciences, médicales considérées sous le rapport théorique et pratique.] Béchet, Paris, 1832. [French]

[12] Bell LV. On a form of disease resembling some advanced stages of mania and fever. Am J Insanity 1849; 6: 97-127.

[13] Stauder KH. Lethal catatonia. [Die tödliche Katatonie.] Arch Psychiatr Nervenkr. 1934; 102: 614-634. [German]

[14] Oldham MA, Lee HB. Catatonia vis-à-vis delirium: the significance of recognizing catatonia in altered mental status. Gen Hosp Psychiatry 2015; 37: 554-559.

[15] Baltzer Nielsen S, Stanislaus S, Saunamäki K, et al. Can acute stress be fatal? A systematic cross-disciplinary review. Stress 2019; 22: 286-294.

[16] Primavera A, Fonti A, Novello P, et al. Epileptic seizures in patients with acute catatonic syndrome. J Neurol Neurosurg Psychiatry 1994; 57: 1419-1422.

[17] Verbraeken R, Luykx JJ. Persistent catatonia following epileptic seizures: a case report and systematic literature search. BMC Psychiatry $2018 ; 18: 350$.
[18] Gjessing R, Gjessing L. Some main trends in the clinical aspects of periodic catatonia. Acta Psychiatr Scand. 1961; 37: 1-13.

[19] Hirjak D, Rashidi M, Kubera KM, et al. Multimodal magnetic resonance imaging data fusion reveals distinct patterns of abnormal brain structure and function in catatonia. Schizophr Bull. 2020; 46: 202-210.

[20] Brosius CM. The catatonia. [Die Katatonie.] AZP 1877; 35: 770-802, 775-776. [German]

[21] Kiernan JG. Katatonia, a clinical form of insanity. Am J Insanity 1877; 34: 59-91, 71, 86.

[22] Szirtes Gy. Development of Lipótmező between 1900 and 1945. In: Szabó Z, Böszörményi Z, Kuntner M. (eds.) Hundred years of the National Institute of Neurology and Psychiatry. [Lipótmező fejlődése 1900 és 1945 között. In: Szabó Z, Böszörményi Z, Kuntner M. (szerk.) Az Országos Ideg- és Elmegyógyintézet 100 éve.] Országos Ideg- és Elmegyógyintézet, Budapest, 1986; pp. 83-96. [Hungarian]

\section{"Bonum quod est supprimitur, numquam exstinguitur." (A jót csak elfojtani lehet, de megsemmisíteni nem.)}

(Gazdag Gábor dr., Budapest, Köves út 1., 1204 e-mail: gazdag@lamb.hu)

\footnotetext{
A cikk a Creative Commons Attribution 4.0 International License (https://creativecommons.org/licenses/by/4.0/) feltételei szerint publikált Open Access közlemény melynek szellemében a cikk bármilyen médiumban szabadon felhasználható, megosztható és újraközölhető, feltéve, hogy az eredeti szerző és a közlés helye, illetve a CC License linkje és az esetlegesen végrehajtott módositások feltüntetésre kerülnek. (SID_1)
} 